\title{
The Impact of COVID-19 and Lockdown on Plastic Surgery Training and Practice in India
}

\author{
Dharini $^{1} \quad$ Shalabh Kumar ${ }^{1} \quad$ Amrita More ${ }^{1, \odot}$ Mandara Harikar ${ }^{2}$ \\ ${ }^{1}$ Department of Burns, Plastic and Maxillofacial Surgery, Vardhaman \\ Mahavir Medical College and Safdarjung Hospital, New Delhi, India \\ 2 Independent Researcher, India \\ Address for correspondence Dr Dharini, MS, MRCS, (MCh), \\ \#139B, Mogra Homes, Humayunpur, Safdarjung Enclave B-6, \\ New Delhi 110029, India (e-mail: dharinitumkur993@gmail.com).
}

Indian J Plast Surg:2020;53:273-279

\begin{abstract}
Keywords

- coronavirus

- COVID-19

- lockdown

- plastic surgery training

- plastic surgery in India

Background A nationwide lockdown due to the outbreak of COVID-19 has posed unforeseen challenges. Lockdown, physical distancing, and restrictions on medical practice have affected the training of residents and the professional and personal life of plastic surgeons. An online survey was conducted to assess this impact.

Methods A questionnaire was circulated on Whatsapp groups from 15 to 21 of May and snowball sampling was done. The survey was designed to have a separate set of questions for residents and practitioners. The obtained results were analyzed, according to SPSS software version 25.

Results A total of 206 responses were obtained (107 residents and 96 consultants) from across the country. The average age of consultants was 38.10 years, with mean experience of 4 years (range $0.5-33$ years). As much as $56.3 \%$ of practitioners and $87.8 \%$ of residents were working in hospitals treating COVID-19. Average fall in number of OPD cases and elective surgeries was $75 \%$. This led to financial strain on $86.5 \%$ of consultants and adversely affected training of $86 \%$ residents. As much as $86.9 \%$ of residents and $67.7 \%$ of consultants hoped that the online teaching pattern continued after the pandemic.

Conclusion Universities need to recognize the loss in training for residents due to the pandemic and formulate plans to overcome it. Institutions and associations conducting webinars can streamline and archive them for future use.
\end{abstract}

\section{Introduction}

The outbreak of novel Coronavirus Disease (COVID-19) pandemic has posed an onerous challenge to the medical world. Although the first case was reported in Wuhan, China, back in December 2019, it was after almost 2 months that India reported its first case on January 30, 2020. ${ }^{1}$ After the WHO declared it as a pandemic on March 11, we were compelled to adapt to an unprecedented lifestyle. ${ }^{2}$

The government of India called for a nationwide lockdown starting from March 24, which was lauded by the WHO as "tough and timely." ${ }^{3}$ The CDC and the Ministry of Health and Family Welfare, Government of India issued guidelines which precluded OPD and elective surgeries during the pandemic. ${ }^{4,5}$
With elective surgery comprising the bulk of plastic surgery practice, our specialty sustained a major blow.

Technology has taken over teaching and medical help via virtual teaching and telemedicine in times of physical distancing. Thus, we conducted a survey to assess the impact of COVID-19 on plastic surgery training and practice, with the intention of getting inputs from consultants and residents themselves.

\section{Materials and Methods}

An observational, cross-sectional study design was adopted. The study protocol involved the circulation of an online
License terms

(1) (1) $\ominus \circledast$ 
survey, addressing the impact of COVID-19 pandemic on the professional and personal lives of plastic surgeons, including residents in India.

Consultants practicing plastic surgery, and residents currently pursuing $\mathrm{MCh}$ or DNB plastic surgery in Government or private colleges in India were included in the study.

After introduction and informed consent, the survey was designed to branch off into two sets of questions for consultants and residents. The questionnaire was divided into multiple sections under the following headings: personal details, COVID-19 duties, impact on practice, academics, apprehensions and personal life. The questionnaire was tested on qualified volunteers for comprehension, length and relevance. The survey was anonymized to minimize response bias.

The survey was then distributed among social media platforms (mainly Whatsapp groups) and snowball sampling was used. The survey was active between May 15 to 21, 2020, wherein all the responses were obtained. Statistical analysis was performed with SPSS software, version 25 (SPSS, Inc., Chicago, IL, USA).

\section{Results}

A total of 206 responses were received, three of which were excluded due to nonprovision of consent. As many as $96(47.29 \%)$ of the respondents were plastic surgery consultants, while 107 (52.70\%) were residents. State-wise distribution of responses is shown in - Fig. 1.

The responses received are tabulated separately for consultants in $\boldsymbol{-}$ Table $\mathbf{1}$ and residents in $\boldsymbol{- T a b l e ~} \mathbf{2}$.

\section{Discussion}

With the largest lockdown in the world being lifted after a long drawn 60 days in a staggered manner, we have to learn to live with the COVID-19. Just as everyone is being advised to take personal protective measures and maintain physical distance, plastic surgery practice and teaching also needs to come up with new measures.

Speaking of gradual change, gender distribution of consultants and residents is not only reflective of the current statistics but is also indicative of the rising proportion of female plastic surgeons. ${ }^{6}$

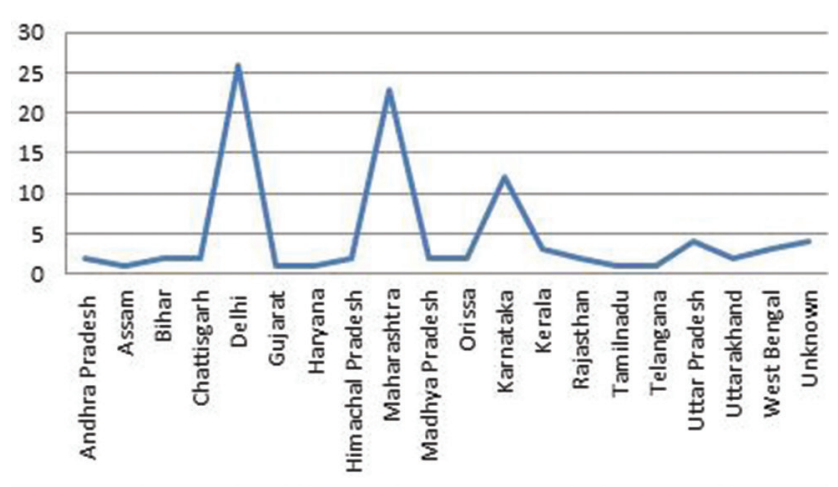

Fig. 1 State-wise distribution of consultants represents the highest response from Delhi, followed by Maharashtra and Karnataka.
Guidelines were issued by the Ministry of Health and Family Welfare to include residents and trainees in different capacities, according to their clinical abilities to fight the pandemic. ${ }^{7}$ Conversion of teaching hospitals into exclusive COVID-19 hospitals and posting residents for COVID-19 duty directly contributes to loss of training. Even in hospitals treating both COVID-19 and non-COVID-19 patients, involvement of residents in noneducational work, limited range of patient exposure and surgeries performed ( - Fig. 2) hampers acquiring and preserving surgical skills. As much as $86 \%$ of residents are of the opinion that their clinical and operative skills are affected by the pandemic, and $60.7 \%$ feared that this will render them less competent.

Conventional methods of training like classroom teaching, grand rounds, and operative teaching have become sparse if not completely stopped. Around half of the institutes had changed over to online teaching ( - Table 2). Although virtual teaching is an effective alternative to share knowledge, its usefulness in terms of building up or improving one's skill set is doubtful. As much as $62 \%$ of residents felt that virtual teaching was less effective. Real-time experience of patient examination and performing a surgery under guidance cannot be matched by virtual modes. ${ }^{8}$

The sudden surge of online teaching via webinars by various teaching institutes and associations (both national and international) has resulted in an average of more than 2 or 3 classes a day, making it difficult for residents and young surgeons to choose and follow. But on the bright side, the gap in different subspecialty teaching in conventional training can be filled with the wide range of online classes available.

Conducting research work in the form of dissertation is recommended by the MCI. ${ }^{9}$ As much as $72 \%$ of residents and $36.5 \%$ of practitioners stated their research work was adversely affected. Enrolling new patients on studies as well as follow-up of already enrolled subjects has proven cumbersome. However, on the brighter side, $20 \%$ of residents utilized their free time academically to write scientific papers.

Residents expected to graduate in July 2020 and December 2020 showed highest apprehension about postponement of examinations. Lack of communication from universities also adds to such fears in this uncertain time.

As much as $56.5 \%$ of residents fear that their future job prospects or fellowship opportunities will suffer. Restriction on international travel has brought down the benefits of fellowship opportunities. Concerns regarding successful grant of VISA, range of exposure because of lesser surgeries, and risk of contracting the disease, all weigh heavy on the shoulders of residents and young surgeons alike.

With around 75\% reduction in the number of OPD cases and surgeries performed by practicing surgeons, reduction in income is imminent. Surgeons affiliated to nonteaching private hospitals are the worst affected in terms of financial burden (-Fig. 3).

As much as $46.2 \%$ of participants found that operating in a PPE is more demanding. Wearing a full personal protective equipment (PPE) with goggles and face shield can interfere with vision when operating under a microscope or wearing loupes. Wearing N95 masks for prolonged hours also has questionable 
The Impact of COVID-19 on Plastic Surgery Training and Practice Dharini et al. 275

Table 1 Showing responses of practicing plastic surgeons

\begin{tabular}{|c|c|c|c|}
\hline Variable & & Mean & SD \\
\hline Age & & 38.1 & 6.59 \\
\hline \multirow[t]{2}{*}{ Plastic surgery experience posttraining (in years) } & & 5.71 & 6.77 \\
\hline & & $n$ & $\%$ \\
\hline \multirow[t]{2}{*}{ Gender } & Male & 78 & 81.25 \\
\hline & Female & 18 & 18.75 \\
\hline \multirow[t]{4}{*}{ Affiliation } & Government hospital teaching & 23 & 23.96 \\
\hline & Government hospital nonteaching & 4 & 4.17 \\
\hline & Private hospital teaching & 25 & 26.04 \\
\hline & Private hospital nonteaching & 57 & 59.38 \\
\hline \multirow[t]{3}{*}{ The hospital that you are working at currently treats } & Only COVID-19 patients & 1 & 1.04 \\
\hline & Only non-COVID-19 patients & 41 & 42.71 \\
\hline & Both & 54 & 56.25 \\
\hline \multirow[t]{4}{*}{ Does your department conduct OPD's during the pandemic? } & Yes, physical OPD & 36 & 37.50 \\
\hline & Yes, telemedicine & 5 & 5.21 \\
\hline & Both & 35 & 36.46 \\
\hline & No & 20 & 20.83 \\
\hline \multirow{4}{*}{$\begin{array}{l}\text { How does performing surgeries in PPE affect your surgical } \\
\text { performance? }\end{array}$} & Adversely & 48 & 50.00 \\
\hline & Have not operated in PPE & 37 & 38.54 \\
\hline & No difference & 8 & 8.33 \\
\hline & Positively & 3 & 3.13 \\
\hline \multirow{3}{*}{$\begin{array}{l}\text { Has the pandemic adversely affected any research work you } \\
\text { are pursuing? }\end{array}$} & Yes & 35 & 36.46 \\
\hline & No & 15 & 15.63 \\
\hline & Not applicable & 46 & 47.92 \\
\hline \multirow{2}{*}{$\begin{array}{l}\text { Has a conference that you had planned to attend been } \\
\text { cancelled due to the COVID-19 pandemic? }\end{array}$} & Yes & 76 & 79.17 \\
\hline & No & 20 & 20.83 \\
\hline \multirow{2}{*}{$\begin{array}{l}\text { Have you attended any third-party webinars during the } \\
\text { pandemic? }\end{array}$} & Yes & 87 & 90.63 \\
\hline & No & 9 & 9.37 \\
\hline \multirow[t]{2}{*}{ Have you organized or been invited as faculty to any webinar? } & Yes & 19 & 19.79 \\
\hline & No & 77 & 80.20 \\
\hline \multirow{2}{*}{$\begin{array}{l}\text { Do you hope the virtual teaching culture becomes main- } \\
\text { stream after COVID-19 pandemic? }\end{array}$} & Yes & 65 & 67.71 \\
\hline & No & 31 & 32.29 \\
\hline \multirow{5}{*}{$\begin{array}{l}\text { How are you spending time academically during the } \\
\text { pandemic? }\end{array}$} & Self-study & 63 & 65.63 \\
\hline & Scientific writing/publications & 43 & 44.79 \\
\hline & Attending classes/webinars & 73 & 76.04 \\
\hline & Conducting classes/webinars & 83 & 86.46 \\
\hline & Spending time academically others & 10 & 10.42 \\
\hline \multirow{2}{*}{$\begin{array}{l}\text { Do you feel that the COVID } 19 \text { pandemic has/will adversely } \\
\text { impact the training of plastic surgery residents? }\end{array}$} & Yes & 90 & 93.75 \\
\hline & No & 6 & 6.25 \\
\hline \multirow{6}{*}{$\begin{array}{l}\text { How are you spending time nonacademically during the } \\
\text { pandemic? }\end{array}$} & Quality time with family & 88 & 91.67 \\
\hline & Hobbies/passions & 52 & 54.17 \\
\hline & $\begin{array}{l}\text { Learning new skills (not related to } \\
\text { surgery) }\end{array}$ & 60 & 62.50 \\
\hline & Physical fitness & 62 & 64.58 \\
\hline & Spiritual activities & 22 & 22.92 \\
\hline & Others & 8 & 8.33 \\
\hline \multirow[t]{2}{*}{ Has the pandemic caused a financial strain on you? } & Yes & 71 & 73.96 \\
\hline & No & 25 & 26.04 \\
\hline
\end{tabular}


Table 1 (Continued)

\begin{tabular}{|c|c|c|c|}
\hline Variable & & $n$ & $\%$ \\
\hline \multirow{6}{*}{$\begin{array}{l}\text { Can you quantify the reduction in your monthly income } \\
\text { because of the pandemic? }\end{array}$} & No impact & 13 & 13.54 \\
\hline & $<25 \%$ & 11 & 11.46 \\
\hline & $25-50 \%$ & 27 & 28.13 \\
\hline & $50-75 \%$ & 16 & 16.67 \\
\hline & $>75 \%$ & 20 & 20.83 \\
\hline & Cannot say & 9 & 9.38 \\
\hline \multirow[t]{3}{*}{ Work-life balance during the pandemic has: } & Improved & 51 & 53.13 \\
\hline & Same & 13 & 13.54 \\
\hline & Worsened & 32 & 33.33 \\
\hline \multirow{3}{*}{$\begin{array}{l}\text { Work related stress during the pandemic } \\
\text { has- }\end{array}$} & Increased & 36 & 37.50 \\
\hline & Reduced & 49 & 51.04 \\
\hline & Same & 11 & 11.46 \\
\hline \multirow{2}{*}{\multicolumn{2}{|c|}{ On average, how many patients did you see in your OPD per day, before the COVID-19 pandemic? }} & Mean & SD \\
\hline & & 24.839 & 30.6283 \\
\hline \multicolumn{2}{|c|}{ On average, how many patients do you see in your OPD per day, during the COVID-19 pandemic? } & 5.13 & 8.186 \\
\hline \multicolumn{2}{|c|}{ What percentage of your patients were emergencies before the COVID-19 pandemic? } & 35.69 & 25.981 \\
\hline \multicolumn{2}{|c|}{ What percentage of your patients are emergencies during the COVID-19 pandemic? } & 57.92 & 40.256 \\
\hline \multicolumn{2}{|c|}{ How many surgeries did you perform/assist in a month before the COVID-19 pandemic? } & 32.98 & 18.686 \\
\hline \multicolumn{2}{|c|}{ How many surgeries do you perform/assist in a month, during the COVID-19 pandemic? } & 7.98 & 8.498 \\
\hline
\end{tabular}

Abbreviations: OPD, outpatient department; PPE: personal protective equipment.

compliance. ${ }^{10}$ Since PPE is becoming the new norm, further studies are required to objectively assess the impact of PPE on surgical performance, especially in microsurgery.

Many studies have reported increased mental burden on healthcare workers, especially the frontliners. Our survey found that $47.2 \%$ of residents complained of increased work-related stress. Khanna et al reported increased rates of depression among ophthalmologists in India. ${ }^{11}$ Increased stress is due to an increasing number of COVID-19 cases, uncertainty about the situation, inherent risk of contracting the disease, fear of spreading the disease to family members, reduction in income, stigmatization of healthcare workers, and loss of training. ${ }^{12}$

\section{What can be Done?}

Streamlining of webinars-centers of excellence and other teaching institutes can collaborate with the curriculum committee of Association of Plastic Surgeons of India (APSI) and other associations to structure the teaching program, according to their respective area of expertise. As a parallel benefit of the pandemic, international faculty are available to share knowledge across the globe.

Didactic mode of teaching can be avoided by including operative planning, how I do it videos, journal clubs, etc. Selfevaluation must be done after each session to assess effectiveness. All teaching webinars can be recorded and archived and made accessible for future reference.
Many universities have already relaxed the submission date for dissertations, and some have started conducting online examinations. Directors of Medical colleges and Universities can recognize the impact of COVID-19 on plastic surgery training and can formulate plans to overcome the same.

As a measure to prevent cancellation of conferences, which provide the opportunity to residents to present their research work as papers and posters, they can be organized virtually. To cater to the overwhelming number of delegates online, they can be divided in a segregated manner. Telemedicine can be incorporated into daily practice for the mutual benefit of patients and doctors.

\section{To Preserve Surgical Skills}

It is the best time to practice microsurgery in a laboratory. In institutions having microlaboratory with a simulator, rosters can be made for its usage to cope with the loss of elective OT time. If there is unavailability of laboratory or simulators, practice could be done using loupes. It is time to get creative in finding ways to practice, for example, self-made cartilage carving simulator using an eraser. ${ }^{13}$

Many online applications are available for anatomy and surgical practice like Netter's Anatomy flash cards, Skin atlas, and Gray's anatomy. "Anatomage Table" (San Jose, CA, USA) provides a unique 3D experience. "Touch Surgery" application has a wide range of surgeries, with 42 of them being plastic surgeries. ${ }^{14}$ 
Table 2 Table Showing responses of residents

\begin{tabular}{|c|c|c|c|}
\hline & & $n$ & $\%$ \\
\hline \multirow[t]{3}{*}{ Gender } & Male & 76 & 71.03 \\
\hline & Female & 30 & 28.04 \\
\hline & Others & 1 & 0.93 \\
\hline \multirow[t]{6}{*}{ When are you scheduled to give your M. Ch/DNB final exams? } & July 2020 & 29 & 27.10 \\
\hline & December 2020 & 9 & 8.41 \\
\hline & July 2021 & 33 & 30.84 \\
\hline & December 2021 & 3 & 2.80 \\
\hline & July 2022 & 28 & 26.17 \\
\hline & December2022 & 5 & 4.67 \\
\hline \multirow[t]{3}{*}{ The hospital you are working at currently treats: } & Only COVID-19 patients & 15 & 14.02 \\
\hline & Only non-COVID-19 patients & 13 & 12.15 \\
\hline & Both & 79 & 73.83 \\
\hline \multirow[t]{2}{*}{ Have you been posted in COVID-19 related duties? } & Yes & 49 & 45.79 \\
\hline & No & 58 & 54.20 \\
\hline \multirow{4}{*}{$\begin{array}{l}\text { During the COVID-19 pandemic, has your department been } \\
\text { conducting OPDs? }\end{array}$} & Yes, physical OPD & 58 & 54.21 \\
\hline & Yes, telemedicine & 8 & 7.48 \\
\hline & Both & 10 & 9.35 \\
\hline & No & 31 & 28.97 \\
\hline \multirow{4}{*}{$\begin{array}{l}\text { How does performing surgeries in PPE affect your surgical } \\
\text { performance? }\end{array}$} & Adversely & 50 & 46.73 \\
\hline & Have not operated in PPE & 37 & 34.58 \\
\hline & No difference & 18 & 16.82 \\
\hline & Positively & 2 & 1.87 \\
\hline \multirow{3}{*}{$\begin{array}{l}\text { What platform does your department use to conduct academic } \\
\text { sessions? }\end{array}$} & Academic sessions have been stopped & 29 & 27.10 \\
\hline & Classroom & 18 & 16.82 \\
\hline & Video conferencing & 60 & 56.07 \\
\hline \multirow[t]{3}{*}{$\begin{array}{l}\text { In your opinion, which is the best way to conduct academic sessions } \\
\text { during the pandemic? }\end{array}$} & $\begin{array}{l}\text { Best to withhold classes till the pan- } \\
\text { demic is relatively controlled }\end{array}$ & 13 & 12.15 \\
\hline & Classroom & 6 & 5.61 \\
\hline & Video conferencing & 88 & 82.24 \\
\hline \multirow{4}{*}{$\begin{array}{l}\text { According to you, the video conference teaching when compared with } \\
\text { regular classroom teaching is }\end{array}$} & Less effective & 66 & 61.68 \\
\hline & More effective & 21 & 19.63 \\
\hline & Equal & 10 & 9.35 \\
\hline & Others & 10 & 9.35 \\
\hline \multirow[t]{4}{*}{ Teaching rounds during the pandemic: } & Have stopped & 48 & 44.86 \\
\hline & Occur at the same frequency as earlier & 12 & 11.21 \\
\hline & $\begin{array}{l}\text { Occur less frequently than before the } \\
\text { pandemic }\end{array}$ & 39 & 36.45 \\
\hline & $\begin{array}{l}\text { Occur more frequently than before the } \\
\text { pandemic }\end{array}$ & 8 & 7.48 \\
\hline \multirow{2}{*}{$\begin{array}{l}\text { Has the pandemic adversely affected your thesis work or any research } \\
\text { work you are pursuing? }\end{array}$} & Yes & 77 & 71.96 \\
\hline & No & 30 & 28.03 \\
\hline \multirow{2}{*}{$\begin{array}{l}\text { Has a conference you had planned to attend been cancelled due to the } \\
\text { COVID-19 pandemic? }\end{array}$} & Yes & 75 & 70.09 \\
\hline & No & 32 & 29.90 \\
\hline \multirow[t]{3}{*}{ How are you spending time academically during the pandemic? } & Self-study & 72 & 67.29 \\
\hline & Scientific writing/publications & 20 & 18.69 \\
\hline & Attending classes/webinars & 98 & 91.59 \\
\hline
\end{tabular}


Table 2 (Continued)

\begin{tabular}{|c|c|c|c|}
\hline & & $n$ & $\%$ \\
\hline \multirow[t]{6}{*}{ What improvements to third party webinars would you like to see? } & Longer duration & 9 & 8.41 \\
\hline & Shorter duration & 40 & 37.38 \\
\hline & Content in less detail & 6 & 5.61 \\
\hline & Content in more detail & 53 & 49.53 \\
\hline & $\begin{array}{l}\text { Simpler subjects that are more catered } \\
\text { to residents }\end{array}$ & 77 & 71.96 \\
\hline & Others & 4 & 3.74 \\
\hline \multirow{2}{*}{$\begin{array}{l}\text { Do you find third party webinars to be better than the academic } \\
\text { sessions held by your department? }\end{array}$} & Yes & 67 & 62.62 \\
\hline & No & 40 & 37.38 \\
\hline \multirow[t]{2}{*}{ Do you want the third-party webinars to continue post the pandemic? } & Yes & 93 & 86.92 \\
\hline & No & 14 & 13.08 \\
\hline \multirow{2}{*}{$\begin{array}{l}\text { Do you feel the COVID-19 pandemic has adversely impacted your } \\
\text { plastic surgery training in terms of clinical and operative skills? }\end{array}$} & Yes & 92 & 85.98 \\
\hline & No & 15 & 14.01 \\
\hline \multirow{2}{*}{$\begin{array}{l}\text { Do you fear that the COVID-19 pandemic will render you less } \\
\text { competent than those who did not face the pandemic during their } \\
\text { residency? }\end{array}$} & Yes & 65 & 60.75 \\
\hline & No & 42 & 39.25 \\
\hline \multirow[t]{2}{*}{ Do you fear that your examinations will be rescheduled/deferred? } & Yes & 65 & 60.75 \\
\hline & No & 42 & 39.25 \\
\hline \multirow{2}{*}{$\begin{array}{l}\text { Do you feel that this time lost in training will affect your future job } \\
\text { prospects/fellowship opportunities? }\end{array}$} & Yes & 61 & 57.01 \\
\hline & No & 46 & 42.99 \\
\hline \multirow{5}{*}{$\begin{array}{l}\text { How do you plan on compensating for loss in training due to the } \\
\text { COVID-19 training? }\end{array}$} & Extended residency & 40 & 37.38 \\
\hline & Fellowship & 66 & 61.68 \\
\hline & Study more & 56 & 52.34 \\
\hline & Work more & 2 & 1.87 \\
\hline & Others & 6 & 5.61 \\
\hline \multicolumn{2}{|l|}{ 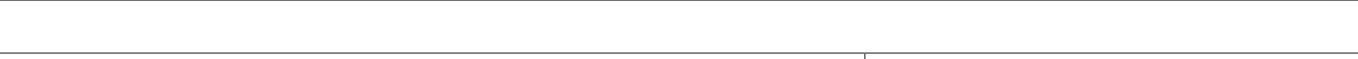 } & Mean & SD \\
\hline $\begin{array}{l}\text { How many surgeries you used to perform/assist per month before the } \\
\text { COVID-19 pandemic? }\end{array}$ & & 54.3 & 45.54 \\
\hline $\begin{array}{l}\text { How many surgeries do you perform/assist per month, since the start } \\
\text { of the COVID-19 pandemic? }\end{array}$ & & 11.89 & 17.06 \\
\hline $\begin{array}{l}\text { How many academic sessions did your department conduct per week } \\
\text { before the COVID-19 pandemic? }\end{array}$ & & 4.12 & 3.35 \\
\hline $\begin{array}{l}\text { How many academic sessions does your department conduct per } \\
\text { week during the COVID-19 pandemic? }\end{array}$ & & 3.01 & 3.03 \\
\hline
\end{tabular}

Abbreviations: OPD, outpatient department; PPE: personal protective equipment.

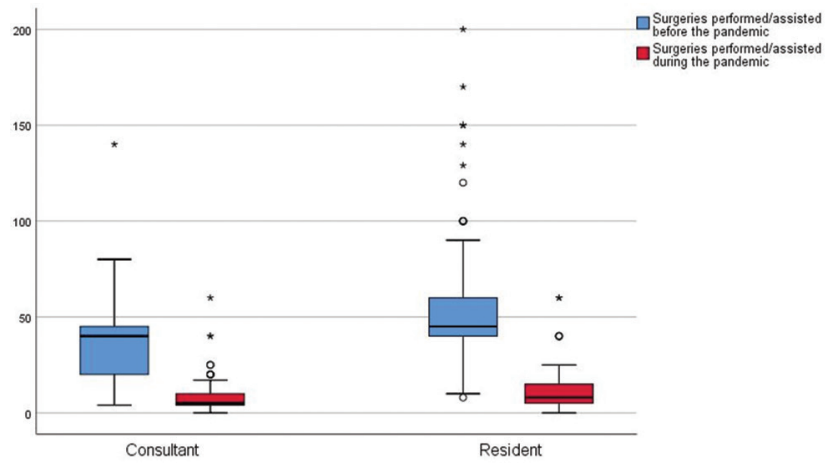

Fig. 2 Drop in the number of surgeries performed per month by resident and consultant groups.

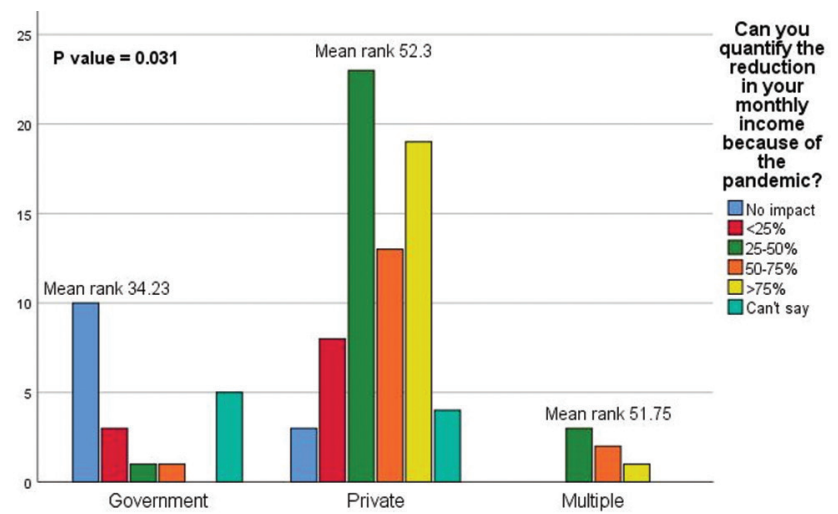

Fig. 3 Percentage reduction in income, according to type of affiliation. While most surgeons working in government institutes said there was no reduction in income, more private practitioners suffered a drop between 25 to $50 \%$ with a mean of 52.3 . 


\section{Better Utilization of Time}

We can redirect the free time toward academic work and research work. We can also pursue our long forgotten hobbies, especially sketching, drawing and painting to stimulate our right brain. Many plastic surgery procedures like rhinoplasty, breast reduction, and flap shaping for reconstruction have been proven to be a work of the right brain. ${ }^{15}$

Self-care can incorporate fitness regimes, eating healthy, timely diet, and spending quality time with family.

Telemedicine can be incorporated into daily practice, which can help serve the patients better with physical distancing, especially when long follow-ups are required.

\section{Limitation of the Study}

Like all surveys, this study also has the inherent limitation of self-reporting, limited cross-section sample and snowball sampling. Validation of reduction in the number of surgeries and attrition of skills was not possible due to practical issues. The duration of the survey was kept short to increase the scientific value by early reporting.

\section{Conclusion}

Lockdown because of the pandemic has affected training, practice, and income in both government and private sectors. However, it also brought us closer to technology, which is the way ahead. The complete effect of the pandemic is yet to unfold and it can be assessed only after our lives get back to the pre-COVID era. We should apply the wisdom gained during the pandemic for the betterment of practice and teaching curriculum.

\section{Author Contributions}

Dr Dharini-conceptualization, data curation, methodology, formal analysis, and writing original draft.

Dr Shalabh Kumar-conceptualization, writing review, and editing.

Dr Amrita More-conceptualization, data curation, writing review, and editing.

Dr Mandara Harikar-formal analysis, writing review, and editing.

\section{Conflicts of Interest}

None of the authors have any conflicts of interest to disclose.

\section{References}

1 Wang C, Horby PW, Hayden FG, Gao GF. A novel coronavirus outbreak of global health concern. Lancet 2020;395(10223) $: 470-473$

2 WHO. WHO Director-General's opening remarks at the media briefing on COVID-19 - 11 March 2020. Available at: https:// www.who.int/dg/speeches/detail/who-director-general-sopening-remarks-at-the-media-briefing-on-covid-19-11march-2020. Accessed June 2, 2020

3 The Lancet. India under COVID-19 lockdown. Lancet Lond Engl 2020;395(10233):1315

4 MOHFW. Advisory for Hospitals and Medical Education Institutions. Available at: https://www.mohfw.gov.in/ pdf/ AdvisoryforHospitalsandMedicalInstitutions.pdf. Accessed June 2, 2020

5 CDC. Coronavirus Disease 2019 (COVID-19). Available at: https://www.cdc.gov/ coronavirus/2019-ncov /hcp/ framework-non-COVID-care.html. Accessed June 2, 2020

6 American Society of Plastic Surgeons. Women underrepresented in plastic surgery. Available at: https://www.plasticsurgery.org / news/ press-releases/ women-underrepresented-in-plastic-surgery. Accessed June 19, 2020

7 MOHFW. SOP for reallocation of residents/ PG students and nursing students as part of hospital management of COVID. Available at: https://www.mohfw.gov.in/pdf/ COVID19SOPfordoctorsandnurses.pdf. Accessed June 2, 2020

8 Sutherland LM, Middleton PF, Anthony A, et al. Surgical simulation: a systematic review. Ann Surg 2006;243(3):291-300

9 MCI. P.G. Medical Education Regulations 2000. Available at: https://www.mciindia.org/ CMS/rules-regulations/ p-g-medical-education- regulations-2000. Accessed June 19, 2020

10 Rebmann T, Carrico R, Wang J. Physiologic and other effects and compliance with long-term respirator use among medical intensive care unit nurses. Am J Infect Control 2013;41(12): 1218-1223

11 Khanna RC, Honavar SG, Metla AL, Bhattacharya A, Maulik PK. Psychological impact of COVID-19 on ophthalmologists-in-training and practising ophthalmologists in India. Indian J Ophthalmol 2020;68(6):994-998

12 Balasubramanian A, Paleri V, Bennett R, Paleri V. Impact of COVID-19 on the mental health of surgeons and coping strategies. Head Neck 2020;42(7):1638-1644

13 Erdogan B, Morioka D, Hamada T, Kusano T, Win KM. Use of a plastic eraser for ear reconstruction training. Indian J Plast Surg 2018;51(1):66-69

14 Zingaretti N, Contessi Negrini F, Tel A, Tresoldi MM, Bresadola V, Parodi PC. The impact of COVID-19 on plastic surgery residency training. Aesthetic Plast Surg 2020; (e-pub ahead of print. doi: https://dx.doi.org/ 10.1007\% 2Fs00266- 020-01789-w

15 Edwards B, The New Drawing on the Right Side of the Brain 3rd ed. HarperCollins; 2009 